\title{
Special Issue of Indian Geotechnical Journal: Transportation Geotechnics
}

\author{
Rajagopal Karpurapu $^{1} \cdot$ Carthigesu Gnanendran $^{2} \cdot$ Sireesh Saride $^{3}$
}

Published online: 22 October 2015

(C) Indian Geotechnical Society 2015

Construction of road pavements poses many challenges to a design engineer as the roads should function well in all weather conditions during their design life with low maintenance requirements. Many of the road corridors need to be constructed through problematic soils such as swampy lands or through highly expansive soils. The construction and maintenance of roads in such challenging conditions requires good understanding of the ground conditions and use of appropriate technologies for long lasting roads with minimal maintenance requirements. Another major challenge faced in the road projects is the limited availability of good quality raw materials like granular soils, aggregate, etc.

The design and construction of road pavements involves the expertise of both transportation engineers and geotechnical engineers. Synergy between both engineering groups is a pre-requisite for the success of any road project. This Special Issue of the journal, Transportation Geotechnics, focuses on the common issues in both fields for the understanding of the performance of pavements. Proper understanding results in good quality roads which will serve for a long time.

This special issue carries eleven (11) interesting research papers that highlight different aspects of road pavements. Several innovative techniques for improvement of the performance of flexible pavements are discussed in

Rajagopal Karpurapu

gopalkr@iitm.ac.in

IIT Madras, Chennai, India

2 University of New South Wales, Canberra, Australia

3 IIT Hyderabad, Kandi, Sangareddy, India these papers. A brief summary of these papers is given in the following:

Teltayev and Aibayev [1] have described a finite element procedure to model the temperature distribution within a flexible road base. The influence of temperature on strains and stresses in a flexible pavement was analyzed and compared with the field measured data from Kazakhstan.

Saride et al. [2] have described a laboratory procedure to evaluate the rutting behaviour of geocell treated road bases under repeated loading. The benefit ratio with different geometric properties of geocells and infill materials has been reported.

Kief et al. [3] have described the applications of high modulus geocells made of composites for highway applications. Several successful case studies of the application of this product are discussed and the savings in natural materials due to the use of this innovative geosynthetic product is demonstrated.

Saride et al. [4] have described the fly ash treated reclaimed asphalt pavement (RAP) material for base and subbase applications. The use of RAP leads to the reuse of natural materials and enables sustainable development of road projects.

Foriero et al. [5] have described a new nonlinear crossanisotropic model for analyzing the behaviour of granular layers. The developed constitutive model is applied for the analysis of the behaviour of a flexible pavement.

Based on measured data from over $600 \mathrm{~km}$ of roads in North-West Victoria province in Australia, Evans et al. [6] have proposed new templates to detect gilgai relief patterns below sealed road bases constructed in expansive soils.

Paul et al. [7] have described the damage characteristics of lightly stabilized granular beams under cyclic flexural 
loads. Based on laboratory test data, empirical equations have been developed to estimate the fatigue life of lightly treated granular bases.

Pratibha et al. [8] have described the influence of different parameters like water content, stress levels, etc. on the resilient modulus of granular materials used in pavements. The validity of different existing models for describing the resilient modulus under cyclic loading has been evaluated.

Korulla et al. [9] have described the use of geogrids for design and construction of flexible pavements. A good summary of different design procedures to include the effect of geogrids is discussed in this paper.

The durability of any repair of flexible pavement is a major issue faced in several countries. A number of geosynthetic overlay materials have been developed to extend the life of overlays by controlling the development of reflection cracks. Nithin et al. [10] have made an extensive summary of the existing literature on the topic of reflection cracking in flexible pavements and the observations from several field studies over the last 50 years.

Mallick and Sivakumar Babu [11] discuss the innovative use of geosynthetic chip seals to reduce the temperatures within the flexible pavement by reflecting the heat. This in turn is shown to result in smaller rutting and better long term performance.

We hope that the readers will find these papers useful in furthering their understanding the performance of flexible pavements. Many thanks are due to the Editor in Chief of IGJ for inviting us to guest edit this special volume. Many thanks are also due to all the authors of the papers for their timely contributions. Special thanks are due to the editorial staff of the journal for their wonderful editorial skills in preparing this special volume.

\section{References}

1. Teltayev B, Aibayev K (2015) Modeling of temperature field in flexible pavement. Indian Geotech J. doi:10.1007/s40098-014$0122-6$

2. Saride S, Rayabharapu VK, Vedpathak S (2015) Evaluation of rutting behaviour of geocell reinforced sand subgrades under repeated loading. Indian Geotech J. doi:10.1007/s40098014-0120-8

3. Kief O, Schary Y, Pokharel SK (2015) High-modulus geocells for sustainable highway infrastructure. Indian Geotech J. doi: 10.1007/s40098-014-0129-z

4. Saride S, Avirneni D, Javvadi SCP, Puppala AJ, Hoyos LR (2015) Evaluation of fly ash treated reclaimed asphalt pavement for base/subbase applications. Indian Geotech J. doi: 10.1007/s40098-014-0137-z

5. Foriero A, Tsafack J, Doucet F (2015) A new model for the cross anisotropic nonlinear elastic behavior of unbounded soils for road pavements. Indian Geotech J. doi:10.1007/s40098-014-0126-2

6. Evans RP, Arulrajah A, Horpibulsuk S (2015) Detecting gilgai relief beneath sealed flexible pavements using road profile and road roughness measurements. Indian Geotech J. doi:10.1007/s 40098-015-0164-4

7. Paul DK, Theivakularatnam M, Gnanendran CT (2015) Damage study of a lightly stabilised granular material using flexural testing. Indian Geotech J. doi:10.1007/s40098-015-0158-2

8. Pratibha R, Sivakumar Babu GL, Madhavi Latha G (2015) Stress-strain response of unbound granular materials under static and cyclic loading. Indian Geotech J. doi:10.1007/s 40098-015-0155-5

9. Korulla M, Gharpure A, Rimoldi P (2015) Design of geogrids for road base stabilization. Indian Geotech J. doi:10.1007/s 40098-015-0165-3

10. Nithin S, Rajagopal K, Veeraragavan A (2015) State-of-the art summary of geosynthetic interlayer systems for retarding the reflective cracking. Indian Geotech J. doi:10.1007/s 40098-015-0161-7

11. Mallick RB, Sivakumar Babu GL (2015) Novel use of geosynthetic reinforced chip seal in asphalt pavements. Indian Geotech J. doi:10.1007/s40098-0s15-0168-0 